\title{
Effect of organic matter on phosphorus recovery from sewage sludge subjected to microwave hybrid pretreatment
}

\author{
Yawei Wang ${ }^{1}$, Qingcong Xiao ${ }^{1,2,3}$, Hui Zhong ${ }^{1}$, Xiang Zheng ${ }^{2}$, Yuansong Wei ${ }^{1, *}$ \\ 1. State Key Laboratory of Environmental Aquatic Chemistry, Research Center for Eco-Environmental Sciences, Chinese Academy of Sciences, \\ Beijing 100085, China \\ 2. School of Environment and Natural Resources, Renmin University of China, Beijing 100872, China \\ 3. CSD IDEA (Beijing) Environmental Test\& Analysis Co. Ltd., Beijing 100192, China
}

\section{A R T I C L E I N F O}

Article history:

Received 31 July 2015

Revised 16 October 2015

Accepted 19 October 2015

Available online 8 December 2015

Keywords:

Microwave pretreatment

Sewage sludge

Molecular weight distribution

Phosphorus recovery

Struvite

\begin{abstract}
A B S T R A C T
Microwave (MW) hybrid processes are able to disrupt the flocculent structure of complex waste activated sludge, and help promote the recovery of phosphorus as struvite. In this study, to optimize struvite yield, (1) the characteristics of matter released in MW-hybrid treatments were compared, including MW, MW-acid, MW-alkali, MW- $\mathrm{H}_{2} \mathrm{O}_{2}$, and $\mathrm{MW}-\mathrm{H}_{2} \mathrm{O}_{2}$-alkali. The results showed that selective release of carbon, nitrogen, phosphorus, $\mathrm{Ca}^{2+}$, and $\mathrm{Mg}^{2+}$ achieved by sludge pretreatment using MW-hybrid processes. $\mathrm{MW}-\mathrm{H}_{2} \mathrm{O}_{2}$ is the recommended sludge pretreatment process for phosphorus recovery in the form of struvite. The ratio of $\mathrm{Mg}^{2+}: \mathrm{NH}_{4}^{+}-\mathrm{N}: \mathrm{PO}_{4}^{3-}-\mathrm{P}$ was 1.2:2.9:1 in the supernatant. (2) To clarify the effects of organic matter on struvite recovery, the composition and molecular weight distribution of organic matters were analyzed. Low molecular weight COD was found to facilitate the removal rate of $\mathrm{NH}_{4}^{+}-\mathrm{N}$ and $\mathrm{PO}_{4}^{3}-\mathrm{P}$ via crystallization, and the amorphous struvite crystals $(<1 \mathrm{kDa})$ from the filtered solutions had high purity. Therefore, the present study reveals the necessity of taking into consideration the interference effect of high molecular weight organic matters during struvite crystallization from sewage sludge.

(c) 2015 The Research Center for Eco-Environmental Sciences, Chinese Academy of Sciences.

Published by Elsevier B.V.
\end{abstract}

\section{Introduction}

The amount of sludge produced by biological sewage treatment plants around the world has been constantly increasing. Thus, the treatment and disposal of excess sewage sludge are becoming a challenge for wastewater treatment plants (WWTPs). The challenges have been amplified by current legal constraints, land shortages, rising costs, and public sensitivity. For the purpose of preventing eutrophication, biological nutrient removal (BNR) technologies are used worldwide, wherein phosphorus is locked into the structure and polymers of the sewage sludge.
Phosphate-based fertilizers have helped spur agricultural gains over the past century. However, global phosphorus resources have been rapidly depleted (Gilbert, 2009), and prices continue to soar as this commodity shortage worsens. The phosphorus content of sludge, due to the application of BNR processes, ranges between $4 \%$ and $9 \%$ (Barlindhaug and Odegaard, 1996). Sewage and sludge are the main channels for phosphorus loss to the environment. Therefore, phosphate recovery from sewage sludge could provide a key solution to the phosphate shortage.

One of the main obstacles for sludge reduction and resource recovery is that the complex organic materials that

\footnotetext{
* Corresponding author. E-mail: yswei@rcees.ac.cn (Yuansong Wei).
} 
make up cell walls and membranes protect intracellular materials from biodegradation. In recent studies, sludge pretreatment processes have been of great interest for the release of organic matter, nitrogen, and phosphorus, in order to enhance the anaerobic digestibility of waste activated sludge (WAS) for biogas production. These pretreatment methods also aid the recovery of phosphorus in appropriate forms from WAS (Wong et al., 2006b).

As a promising sludge pretreatment technology, microwave (MW) hybrid pre-treatment is able to disrupt the flocculent structure of complex waste activated sludge (Xiao et al., 2012), which is a key issue for most sludge $3 \mathrm{R}$ (reduce, reuse, and recycle) technologies.

MW and hybrid sludge pretreatment techniques (e.g., MW with pressure) have gained popularity due to the ease of their control and high efficiency. Methods such as MW-acid and MW-alkali (Cheng et al., 2009), MW- $\mathrm{H}_{2} \mathrm{O}_{2}$ (Wong et al., 2006a), and MW coupled with an advanced oxidation process (AOP) have been used to improve sludge dissolution and disinfection. Current studies on sludge pretreatment for sludge reduction have mainly addressed the issues of particle size distribution and the release efficiencies of carbon, nitrogen, and phosphorus (Wang et al., 2015).

Struvite precipitation is an ideal phosphorus recovery technique for sludge because struvite (magnesium ammonium phosphate) is an excellent slow-release fertilizer (Ye et al., 2014). Phosphorus recovery in the form of struvite has earned recognition owing to its technical feasibility and economic viability (Guadie et al., 2014). Sludge pretreatment is designed to maximize the release of organic release simultaneous with $\mathrm{NH}_{4}^{+}-\mathrm{N}, \mathrm{PO}_{4}^{3-}-\mathrm{P}$, and $\mathrm{Mg}^{2+}$, which could reduce the chemical costs of struvite recovery.

The main factors governing struvite crystallization are the initial reaction parameters (e.g., $\mathrm{pH}$, ionic strength, ionic ratio) (Doyle and Parsons, 2002), and the operating parameters (e.g., initial temperature, reaction time, stirring intensity) (Stratful et al., 2001). Although many methods (e.g., mechanical, heat, chemical, and hybrid technologies) have been applied to rupture sludge particles and recover phosphorus ( $\mathrm{Bi}$ et al., 2014), few studies have considered the effect of organic matter on this process. In a previous study, it was found that organic matters with molecular weight $(\mathrm{MWt})<8 \mathrm{kDa}$ acted as a trigger for recover struvite in cat urine (Matsumoto and Funaba, 2008). These authors proposed that a substance of the proper MWt could enhance struvite recovery after sludge pretreatment. However, for pretreated sludge, there are few studies focused on the effects of organic matter on struvite crystallization during phosphorus recovery. Knowledge about the molecular weight distribution (MWtD) of treated sludge is required for its further utilization, but this has not received particular attention. Additionally, the effect of the organicparticle size distribution on the recovery of phosphorus as struvite after WAS pretreatment is still unknown. Furthermore, to date, there has been no research focused on the effect of MW-hybrid sludge treatments on the evaluation of organic matter release characteristics, such as their influence on the MWtD of the organics, or subsequent effects on struvite recovery from sludge.

This study had two goals: The first goal was to investigate the characteristics of sludge disintegration that resulted from
MW-hybrid treatments (i.e., MW, MW-acid, MW-alkali, $\mathrm{MW}-\mathrm{H}_{2} \mathrm{O}_{2}$, and $\mathrm{MW}-\mathrm{H}_{2} \mathrm{O}_{2}$-alkali). These characteristics would first be evaluated in terms of the release of carbon, nitrogen, phosphorus, calcium, and magnesium. They would also be evaluated in terms of the MWtD of the proteins, sugars, and other organics released. The second goal was to investigate the effects of the MWtD of the organic matter in the pretreated sludge on struvite crystallization, to optimize struvite yield and purity.

\section{Materials and methods}

\subsection{Sludge pretreatment by MW-hybrid processes}

Sludge was collected at a wastewater treatment station in Beijing, passed through a 60-mesh screen, then adjusted to a concentration of about $20 \mathrm{~g} / \mathrm{L}$ of mixed liquor suspended solids (MLSS) for batch tests. The WAS characteristics were as follows: MLSS was $18.96 \pm 0.17 \mathrm{~g} / \mathrm{L}$, mixed liquor volatile suspended solids (MLVSS) $11.43 \pm 0.11 \mathrm{~g} / \mathrm{L}$, total chemical oxygen demand (TCOD) $19.21 \pm 0.12 \mathrm{~g} / \mathrm{L}$, total phosphorus (TP) $0.58 \pm 0.05 \mathrm{~g} / \mathrm{L}$, total nitrogen (TN) $0.80 \pm 0.02 \mathrm{~g} / \mathrm{L}$, and $\mathrm{pH}$ was $7.29 \pm 0.03$.

The operational parameters used for sludge pretreatment with the MW-hybrid processes are listed in Table 1 (Wang et al., 2015). One-liter concentrated sludge samples (20 g/L) were treated using MW irradiation. Details of the microwave oven (2450 GHz, $1000 \mathrm{~W}$; Julong, China) were described previously (Wang et al., 2009).

\subsection{Molecular weight distribution of organic matter in the supernatant}

The organic matter in the sludge supernatant mainly consisted of proteins, sugars, and organic acids after microwave pretreatment (Mehdizadeh et al., 2013). The MWtD of the organic matter is influenced by the types of pretreatment and by the operation parameters. The filtration method successfully separated the organic matter for examination of

Table 1-Operational parameters of sludge pretreatment by microwave hybrid processes.

\begin{tabular}{|c|c|}
\hline Processes & Methods of sludge pretreatment \\
\hline MW & $\begin{array}{l}\text { Sludge was heated directly to } 100^{\circ} \mathrm{C} \text { with } \\
\text { microwave (MW) irradiation. }\end{array}$ \\
\hline MW-acid & $\begin{array}{l}\text { The sludge } \mathrm{pH} \text { was adjusted to } 2.5 \text { using a } \\
5.0 \mathrm{~mol} / \mathrm{L} \mathrm{HCl} \text { solution, and then treated with MW. }\end{array}$ \\
\hline MW-alkali & $\begin{array}{l}\text { The sludge } \mathrm{pH} \text { was adjusted to } 10.0 \text { using a } \\
5.0 \mathrm{~mol} / \mathrm{L} \mathrm{NaOH} \text { solution, and then treated } \\
\text { with } \mathrm{MW} \text {. }\end{array}$ \\
\hline $\mathrm{MW}-\mathrm{H}_{2} \mathrm{O}_{2}$ & $\begin{array}{l}\text { The sludge was heated to } 80^{\circ} \mathrm{C} \text { with } \mathrm{MW} \\
\text { irradiation, then } \mathrm{H}_{2} \mathrm{O}_{2} \text { was added at a ratio of } \\
\mathrm{H}_{2} \mathrm{O}_{2}: \mathrm{MLSS}^{\mathrm{a}}=0.2 \text {, with continued heating to } \\
100^{\circ} \mathrm{C} \text { by } \mathrm{MW} \text { irradiation. }\end{array}$ \\
\hline MW-alkali- $\mathrm{H}_{2} \mathrm{O}_{2}$ & $\begin{array}{l}\text { The sludge pH was adjusted to } 10.0 \text { using a } 5.0 \mathrm{~N} \\
\mathrm{NaOH} \text { solution, and then treated as with the } \\
\mathrm{MW}-\mathrm{H}_{2} \mathrm{O}_{2} \text { treatment. }\end{array}$ \\
\hline
\end{tabular}

a Mixed liquor suspended solids; Source: Wang et al., 2015. 
its crystallization. Thus, regenerated cellulose ultrafiltration (UF) membranes in a $200 \mathrm{~mL}$ Millipore 8200 stirred Amicon cell (Millipore Co., USA) were used in this study. Membranes with MWt cutoffs (MwC) of 100, 30, 10, 5, 3, and $1 \mathrm{kDa}$ were arranged in a cascading series. The UF procedure was as follows (Eskicioglu et al., 2006). After rinsing the stirred cell, it was loaded with $180 \mathrm{~mL}$ of primary filtered $(0.45 \mu \mathrm{m})$ and diluted (5:1) supernatants from sludge pretreated with $\mathrm{MW}$, MW-acid, MW-alkali, MW- $\mathrm{H}_{2} \mathrm{O}_{2}$, and MW-alkali- $\mathrm{H}_{2} \mathrm{O}_{2}$. The concentration factor (the ratio of initial volume to retentate volume) was set at 6.0. Sufficient volumes of retentate and permeate were collected from each of the different $\mathrm{MwC}$ membranes (Fig. S1). For permeate and retentate, each $\mathrm{MwC}$ of the UF was analyzed, and the results were expressed in terms of percentage $(w / w)$ of the SCOD, S-proteins (soluble-proteins), and S-sugars (soluble-sugars). The recovery rates of UF were more than $90 \%$ (Table S2).

\subsection{Struvite crystallization}

The preferred MW sludge pretreatment process for struvite crystallization was selected according to the following parameters: the release of carbon, nitrogen, phosphorus, calcium, and magnesium, as well as the ratio of $\mathrm{Mg}^{2+}: \mathrm{NH}_{4}^{+}: \mathrm{PO}_{4}^{3-}$. The unfiltered supernatant $\left(S_{\text {RAW }}\right)$, filtrate of the $0.45 \mu \mathrm{m}$ microfiltration membrane $\left(\mathrm{S}_{\mathrm{MF}}\right)$, filtrate of membranes with $\mathrm{MwC}$ of $10 \mathrm{kDa}\left(\mathrm{S}_{10 \mathrm{~K}}\right)$, and filtrate of membranes with $\mathrm{MwC}$ of $1 \mathrm{kDa}\left(S_{1 \mathrm{~K}}\right)$; were used to recover struvite crystals. Two synthetic solutions $\left(\mathrm{S}_{-\mathrm{Ca}}\right.$ and $\mathrm{S}_{+\mathrm{Ca}}$ ), prepared using $\mathrm{NH}_{4} \mathrm{Cl}$ (0.05 mol), $\mathrm{KH}_{2} \mathrm{PO}_{4}(0.05 \mathrm{~mol})$, and $\mathrm{MgCl}_{2}$ (0.1 mol) solutions, were used as controls during the struvite crystallization experiments. The $\mathrm{C}_{+\mathrm{Ca}}$ solution contained an additional $0.1 \mathrm{~mol} \mathrm{Ca}^{2+}\left(\mathrm{CaCl}_{2}\right)$.

Struvite crystallization has been found to achieve better results at $\mathrm{pH}$ 8.5-10.0, Mg:P ratios of $1-2.5$, and $\mathrm{N}: \mathrm{P}$ ratios $>1$ (Jaffer et al., 2002). The purity of struvite was improved by increasing the concentration of $\mathrm{NH}_{4}^{+}$remaining after crystallization (Doyle and Parsons, 2002). Therefore, the ratio of $\mathrm{Mg}: \mathrm{P}$ was set at '2' by adding $0.05 \mathrm{~mol} \mathrm{MgCl}_{2}$ solution, and maintaining the reaction solution at $\mathrm{pH} 9.7 \pm 0.2$. In addition, the ion losses from solution caused by ultrafiltration were replenished by the addition of $\mathrm{NH}_{4} \mathrm{Cl}(0.05 \mathrm{~mol}), \mathrm{KH}_{2} \mathrm{PO}_{4}$ (0.05 mol), $\mathrm{MgCl}_{2}(0.1 \mathrm{~mol})$, and $\mathrm{CaCl}_{2}(0.1 \mathrm{~mol})$ solutions. The final ion concentrations in the reaction solutions before struvite crystallization were $102.5 \mathrm{mg} / \mathrm{L} \mathrm{NH} \mathrm{NH}_{4}^{+} \mathrm{N}, 74.6 \mathrm{mg} / \mathrm{L}$, $\mathrm{PO}_{4}^{3-}{ }^{-} \mathrm{P}$, and $115.5 \mathrm{mg} / \mathrm{L} \mathrm{Mg}^{2+}$ in all samples (SRAW, $\mathrm{S}_{\mathrm{MF}}, \mathrm{S}_{10 \mathrm{~K}}$, $\mathrm{S}_{1 \mathrm{~K}}, \mathrm{C}_{-\mathrm{Ca}}$, and $\mathrm{C}_{+\mathrm{Ca}}$ ). A concentration of $102.6 \mathrm{mg} / \mathrm{L}$ of $\mathrm{Ca}^{2+}$ was calculated for all samples except sample $\mathrm{C}_{\text {-Ca. }}$. The PHREEQC model (version 3; Parkhurst and Appelo, 2013) was used to simulate the precipitation process.

For MW-treated sludge, the sludge temperature was cooled from $>90^{\circ} \mathrm{C}$ to $50^{\circ} \mathrm{C}$ following filtration and free settling for solid-liquid separation. The temperature of struvite crystallization in this study was set at $(50 \pm 1)^{\circ} \mathrm{C}$ for residual heat utilization in the next step of treatment (i.e., anaerobic fermentation), because temperature has little effect on struvite crystallization. The reaction time of struvite crystallization in this study was set at $20 \mathrm{~min}$ with a stirring rate of $500 \pm 10 \mathrm{rpm}$ through the use of magnetic stirring (Jaffer et al., 2002; Stratful et al., 2001).

\subsection{Analysis}

TCOD, SCOD, TSS (total suspended solids), and VSS (volatile suspended solids) were determined using standard methods (China EPA, 2002). $\mathrm{NH}_{4}^{+}$, total nitrogen (TN), $\mathrm{PO}_{4}^{3-}-\mathrm{P}$, and total phosphorus (TP) were determined using a SmartChem 200 Discrete Analyzer (AMS, France). $\mathrm{Mg}^{2+}$ and $\mathrm{Ca}^{2+}$ were analyzed using an inductively coupled plasma optical emission spectrometry (ULTIMA 2 ICP-OES, France). Sugars and proteins in solution were determined according to the Dubois and Lowry methods (Mehdizadeh et al., 2013). Sludge capillary suction time (CST) was determined using a Triton Type 304 M CST (Triton Electronics, UK). Sludge particle size was determined using a Malvern Mastersizer 2000 (Malvern, UK). Morphological and component analysis of the crystals were conducted with an S-3000 scanning electron microscope (SEM; Hitachi, Japan) and an S-3000 X-ray spectrum analyzer (Hitachi, Japan), respectively.

\section{Results and discussion}

\subsection{Release of organic matter}

As sludge was disrupted in all MW-hybrid pretreatments, extracellular polysaccharides and intracellular substances (cell fragments, proteins, and sugars) were released into the liquid, and were represented by total COD (Fig. 1). The COD concentrations in the supernatant of sludge pretreated by MW-alkali- $\mathrm{H}_{2} \mathrm{O}_{2}, \mathrm{MW}-\mathrm{H}_{2} \mathrm{O}_{2}$, and MW-alkali were much higher (6660, 4725, and $6030 \mathrm{mg} / \mathrm{L}$, respectively), than those observed for the MW and MW-acid treatments. The relative release rate of SCOD was $18.8 \%$, which agrees with a previous report of $15 \%$ to $21 \%$ (Wang et al., 2015).

The release of proteins/S-proteins and sugars/S-sugars presented similar trends (Fig. 1). MW-acid treatment did not perform as well as $\mathrm{MW}-\mathrm{H}_{2} \mathrm{O}_{2}$ or $\mathrm{MW}$-alkali- $\mathrm{H}_{2} \mathrm{O}_{2}$. Interestingly, $\mathrm{MW}$-alkali pretreatment performed as well for total organic

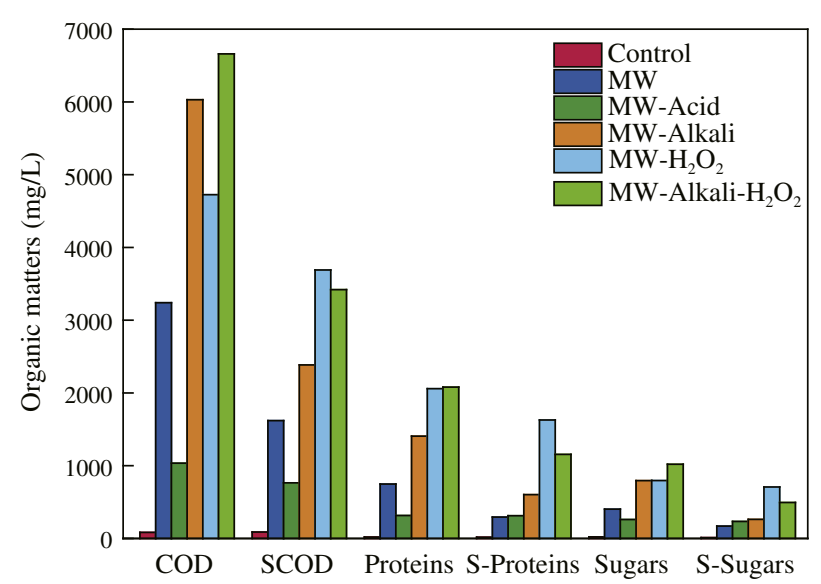

Fig. 1 - Release characteristics of chemical oxygen demand (COD), soluble chemical oxygen demand (SCOD), proteins, soluble proteins (S-proteins), sugars, and soluble sugars (S-sugars). 


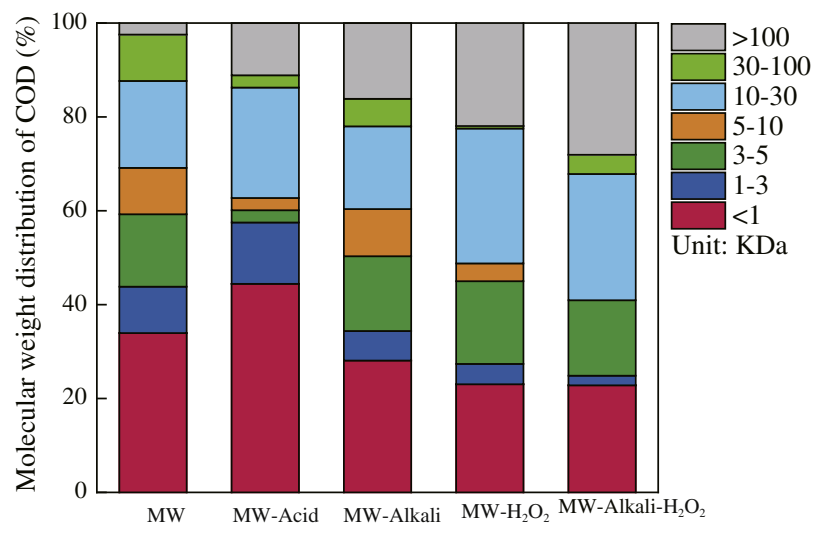

Fig. 2 - Molecular weight distribution of organic matter (represented by SCOD) from sludge pretreated by microwave MW, MW-acid, MW-alkali, MW- $\mathrm{H}_{2} \mathrm{O}_{2}$, and $\mathrm{MW}$-alkali- $\mathrm{H}_{2} \mathrm{O}_{2}$ hybrid pretreatment processes.

matter, proteins, and sugars as the two MW with $\mathrm{H}_{2} \mathrm{O}_{2}$ groups, but performed as badly as the MW and MW-acid treatments in terms of soluble materials. This indicates that the alkali reacts with the cell walls and membranes, making them soluble in a variety of ways. In the release reaction, saponification occurred between alkali and the fatty acids of the cell membranes, changing their permeability, and damaging the cell walls or membrane structure. Therefore, adding alkali can promote the breakdown of organic structures in the sludge and increase the release of particulate organic matter. However, most of the particulate organic matter could not be further hydrolyzed to soluble phases, due to its durable structure or to the short reaction time.

\subsubsection{Molecular weight distribution of organic matter}

The MWtD of organic matter released was strongly affected by the type of pretreatment method used (Fig. 2). The MWtDs of $\mathrm{MW}$-alkali, $\mathrm{MW}-\mathrm{H}_{2} \mathrm{O}_{2}$, and $\mathrm{MW}$-alkali- $\mathrm{H}_{2} \mathrm{O}_{2}$ were evenly distributed in four sets: $<1 \mathrm{kDa}$; $3-5 \mathrm{kDa} ; 10-30 \mathrm{kDa}$; and $>100 \mathrm{kDa}$. Low MWt organics were generated by release and secondary hydrolysis of the proteins by alkali, and by the oxidative decomposition of proteins and sugars. Generally, the MWt of cell-wall fragments, and of extra- and intra-cellular polymers, is $>100 \mathrm{kDa}$. For sludge pretreated by MW, MW-acid, MW-alkali, $\mathrm{MW}-\mathrm{H}_{2} \mathrm{O}_{2}$, and $\mathrm{MW}$-alkali- $\mathrm{H}_{2} \mathrm{O}_{2}$, the organic materials affecting SCOD, with MWt $>100 \mathrm{kDa}$, were 2.5, 11.1, 16.1, 22.0, and 28.1\%, respectively. This indicates that the destruction of sludge structures and cell walls was successfully increased by these pretreatments, in the order given.

The SCOD-affecting organics with MWt $<1 \mathrm{kDa}$ accounted for large proportions $(34.0 \%, 44.4 \%, 28.1 \%, 23.0 \%$, and $22.8 \%$, respectively, for the pretreatments listed above). These were assumed to mainly be organic acids (Barker et al., 1999), which led to the decrease of $\mathrm{pH}$.

For sludge pretreated by MW-hybrid processes, the portions of S-proteins with MWt fraction $<5 \mathrm{kDa}$ were similar, but those $5-100 \mathrm{kDa}$ fractions differed (Fig. S2). For sludge pretreated by MW and MW-acid, most of the S-proteins were 5-30 $\mathrm{kDa}$ (46.8\% and 53.4\%, respectively); for sludge pretreated by $\mathrm{MW}-\mathrm{H}_{2} \mathrm{O}_{2}$ and $\mathrm{MW}$-alkali- $\mathrm{H}_{2} \mathrm{O}_{2}$, most of the S-proteins appeared to be within the MWt range of $10-30 \mathrm{kDa}(41.4 \%$ and $34.0 \%$, respectively). For sludge pretreated by MW-alkali, most of the S-proteins appeared to be in the MWt range of 5-10 kDa (24.0\%) and 30-100 kDa (20.8\%). Pretreatment using MW-alkali, MW- $\mathrm{H}_{2} \mathrm{O}_{2}$, and $\mathrm{MW}$-alkali- $\mathrm{H}_{2} \mathrm{O}_{2}$ can effectively release $\mathrm{S}$-proteins from sludge, and then hydrolyze them to low MWt organics.

The high-MWt proteins were only hydrolyzed to proteins of 30-100 kDa by MW-alkali, but with pretreatment by $\mathrm{MW}-\mathrm{H}_{2} \mathrm{O}_{2}$ and $\mathrm{MW}$-alkali- $\mathrm{H}_{2} \mathrm{O}_{2}$, they were further hydrolyzed to proteins of 10-30 kDa. Similarly, the largest fraction of S-sugar molecules was $10-30 \mathrm{kDa}$ in all pretreatments (Fig. S2), and the next largest fraction was of particles $>100 \mathrm{kDa}$. This showed that the hydrolysis of sugars was difficult even in the presence of alkali and/or $\mathrm{H}_{2} \mathrm{O}_{2}$, because the peptidoglycan material making up bacterial cell walls is durable (Thibault, 2006), so that the sugars in many cells remained inaccessible.

As a separation method, the UF exhibited high reliability, although the interception and adsorption of the organics may be affected by factors such as temperature, $\mathrm{pH}$, ionic strength, molecular structure, and trans-membrane pressure (Eskicioglu et al., 2006; Kuo and Parkin, 1996). In general, all the recovery values in this study were satisfactory (Table S1). The recovery rates from all samples were within the range $91.5 \%-107.4 \%$ for SCOD, S-proteins, $\mathrm{NH}_{4}^{+}-\mathrm{N}$, and $\mathrm{PO}_{4}^{3}-\mathrm{P}$. The lowest recovery rate was $85.2 \%$, for S-sugars in the group treated by MW-alkali- $\mathrm{H}_{2} \mathrm{O}_{2}$.

\subsection{Release of nitrogen, phosphorus, calcium, and magnesium}

Nitrogen and phosphorus were released along with organics during sludge lysis; however, the release patterns of $\mathrm{NH}_{4}^{+}-\mathrm{N}$, soluble total nitrogen (STN), and total nitrogen (TN); $\mathrm{PO}_{4}^{3-}-\mathrm{P}$, soluble total phosphorus (STP) and TP, were different (Fig. 3). The MW-acid process was the most efficient for releasing $\mathrm{PO}_{4}^{3-}-\mathrm{P}, \mathrm{STP}$, and TP. Two other pretreatments, $\mathrm{MW}-\mathrm{H}_{2} \mathrm{O}_{2}$ and MW-alkali, were preferable for the release of $\mathrm{NH}_{4}^{+}-\mathrm{N}$, with relative release rates of $11.3 \%$ and $9.4 \%$, respectively. The results showed that addition of acid and/or $\mathrm{H}_{2} \mathrm{O}_{2}$ facilitated the release of $\mathrm{NH}_{4}^{+}-\mathrm{N}$ and $\mathrm{PO}_{4}^{3}$-P, whereas the addition of alkali was disadvantageous for the release of $\mathrm{NH}_{4}^{+}-\mathrm{N}$. Actually, alkali could improve the permeability of cell membranes (Erdincler and Vesilind, 2000), making it easier for both $\mathrm{NH}_{4}^{+}-\mathrm{N}$

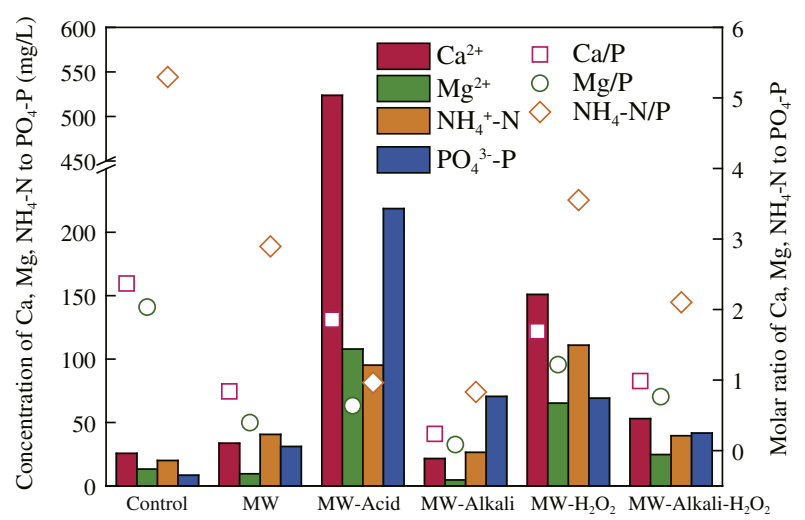

Fig. 3 - Concentration of $\mathrm{Ca}^{2+}$ and $\mathrm{Mg}^{2+}$ in sludge supernatant, and molar ratios of $\mathrm{NH}_{4}^{+}-\mathrm{N}$ : $\mathrm{PO}_{4}^{3}-\mathrm{P}$ and $\mathrm{Mg}^{2+}: \mathrm{PO}_{4}^{3}-\mathrm{P}$ in sludge supernatant; $\mathrm{MW}=$ microwave. 
and $\mathrm{PO}_{4}^{3}$-P to be released. However, at high $\mathrm{pH}$ and temperature, most of the $\mathrm{NH}_{4}^{+}-\mathrm{N}$ released formed $\mathrm{NH}_{3}$, and quickly evaporated into the air. Up to $99.68 \%$ of the nitrogen was in the form of $\mathrm{NH}_{3}$ at $\mathrm{pH} 10$ and $100^{\circ} \mathrm{C}$, which was verified by the PHREEQC model. Additionally, at high $\mathrm{pH}$, part of the phosphorus may be in the form of precipitates, causing high release of TP, but low release of $\mathrm{PO}_{4}^{3}-\mathrm{P}$.

For the release of $\mathrm{Mg}^{2+}$ and $\mathrm{Ca}^{2+}$, the MW-acid process was the most efficient pretreatment (Fig. 3), leaving concentrations of 107.9 and $523.6 \mathrm{mg} / \mathrm{L}$ of $\mathrm{Mg}^{2+}$ and $\mathrm{Ca}^{2+}$ respectively in the sludge supernatant after pretreatment. The next most effective pretreatment was the $\mathrm{MW}-\mathrm{H}_{2} \mathrm{O}_{2}$ process, with $\mathrm{Mg}^{2+}$ and $\mathrm{Ca}^{2+}$ concentrations of 65.2 and $150.9 \mathrm{mg} / \mathrm{L}$, respectively. After MW-hybrid pretreatment, $\mathrm{Mg}^{2+}, \mathrm{NH}_{4}^{+}-\mathrm{N}$, and $\mathrm{PO}_{4}^{3}-\mathrm{P}$ were simultaneously released from the sludge, reducing the cost of chemicals used to release $\mathrm{Mg}^{2+}$ for struvite precipitation.

\subsection{Process selection for struvite crystallization}

MW-hybrid processes were efficient for the release of carbon, nitrogen, and phosphorus, but the relative ratios were very different. $\mathrm{MW}$-acid performed best for $\mathrm{NH}_{4}^{+}-\mathrm{N}$ and $\mathrm{PO}_{4}^{3}-\mathrm{P}$ release, but poorly for organics release. $\mathrm{MW}-\mathrm{H}_{2} \mathrm{O}_{2}$ was efficient for the release of $\mathrm{NH}_{4}^{+}-\mathrm{N}, \mathrm{PO}_{4}^{3-}-\mathrm{P}, \mathrm{SCOD}, \mathrm{S}$-proteins, and S-sugars, which was beneficial for follow-up treatments such as sludge reduction and nutrient recovery. For sludge reduction, $\mathrm{MW}-\mathrm{H}_{2} \mathrm{O}_{2}, \mathrm{MW}$-alkali, and $\mathrm{MW}-\mathrm{H}_{2} \mathrm{O}_{2}$-alkali were preferable due to their high release efficiency for soluble organics. For sludge reduction and nutrient recovery, $\mathrm{MW}-\mathrm{H}_{2} \mathrm{O}_{2}$ was preferable for the high release efficiency for both organics and nutrients $\left(\mathrm{NH}_{4}^{+}-\mathrm{N}\right.$ and $\left.\mathrm{PO}_{4}^{3-}-\mathrm{P}\right)$, and for its improved solidliquid separation after sludge pretreatment.

Phosphorus recovery through struvite crystallization is technically and economically feasible (Shu et al., 2006). The struvite formation reaction can be expressed as follows:

$\mathrm{Mg}^{2+}+\mathrm{NH}_{4}^{+}+\mathrm{PO}_{4}^{3-}+6 \mathrm{H}_{2} \mathrm{O} \rightarrow \mathrm{MgNH}_{4} \mathrm{PO}_{4} \cdot 6 \mathrm{H}_{2} \mathrm{O}$

The solubility of struvite crystals is negatively related to the struvite activity product (SAP; $\left[\mathrm{Mg}^{2+}\right] \times\left[\mathrm{NH}^{4+}\right] \times\left[\mathrm{PO}_{4}^{3-}\right]$ ) (Matsumoto and Funaba, 2008). From Eq. (1), the ratio of $\mathrm{Mg}^{2+}: \mathrm{NH}_{4}^{+}-\mathrm{N}$ : $\mathrm{PO}_{4}^{3}-\mathrm{P}$ is $1: 1: 1$; in practice, struvite crystallization was better when the ratio of $\mathrm{Mg}$ :P was $1-2.5$, and the N:P ratio was $>1$ (Jaffer et al., 2002). The purity of the struvite increased with higher $\mathrm{NH}_{4}^{+}$concentration remaining after crystallization (Doyle and Parsons, 2002). The $\mathrm{Mg}^{2+}: \mathrm{NH}_{4}^{+}-\mathrm{N}$ : $\mathrm{PO}_{4}^{3}-\mathrm{P}$ ratio was 1.2:2.9:1 in the supernatant after sludge was pretreated with $\mathrm{MW}-\mathrm{H}_{2} \mathrm{O}_{2}$ (Fig. S4). This further indicated that $\mathrm{MW}-\mathrm{H}_{2} \mathrm{O}_{2}$ was preferable for struvite recovery.

The $\mathrm{pH}$ affects the concentration of the sludge constituents. Lowering the $\mathrm{pH}$ results in a decrease in the phosphorus concentration present as $\mathrm{PO}_{4}^{3-}$, which is proportionately greater than the increase in the $\mathrm{NH}^{4+}$ concentration (Matsumoto and Funaba, 2008). Additionally, the $\mathrm{pH}$ of sludge pretreated by MW- $\mathrm{H}_{2} \mathrm{O}_{2}$ was 5.72, which not only prevents crystallization during sludge pretreatment, but also prevents scaling of the membrane surface during the follow-up membrane separation. Importantly, at $\mathrm{pH} 5.72$, more than $80 \%$ of the carbon $\left(\mathrm{CO}_{3}^{2-} /\right.$ $\mathrm{HCO}_{3}^{-} / \mathrm{CO}_{2}$ ) in the supernatant was in the form of $\mathrm{CO}_{2}$, and about $20 \%$ was $\mathrm{HCO}_{3}^{-}$. There was almost no $\mathrm{CO}_{3}^{2-}$, which effectively avoided $\mathrm{CaCO}_{3}$ precipitation. For phosphorus recovery as struvite, $\mathrm{Ca}^{2+}$ release was unfavorable. This is because calcium phosphate can be crystallized under certain conditions (such as when $\mathrm{NH}_{4}^{+}-\mathrm{N}$ is insufficient), which affects the purity of the struvite. Therefore, we chose $\mathrm{MW}-\mathrm{H}_{2} \mathrm{O}_{2}$ pretreatment technology for phosphorus recovery via struvite crystallization. After filtration, the COD values in the initial sample solutions for struvite recovery were $4890 \mathrm{mg} / \mathrm{L}$ (S raw), $3360 \mathrm{mg} / \mathrm{L}\left(\mathrm{S}_{\mathrm{MF}}\right)$, $2310 \mathrm{mg} / \mathrm{L}\left(\mathrm{S}_{10 K}\right)$, and $1560 \mathrm{mg} / \mathrm{L}\left(\mathrm{S}_{1 \mathrm{k}}\right)$. In addition, the concentrations of $\mathrm{NH}_{4}^{+}-\mathrm{N}, \mathrm{PO}_{4}^{3-}-\mathrm{P}, \mathrm{Ca}$, and $\mathrm{Mg}$ are shown in Fig. 3, where the ratio of $\mathrm{NH}_{4}: \mathrm{P}$ is $2.87-3.04$ and that of $\mathrm{Mg}: \mathrm{P}$ is $0.60-0.73$.

\subsection{Impacts of organic matter on phosphorus recovery}

The formation and growth of struvite crystals are not determined solely by SAP. Several organic compounds, including proteins and glycosaminoglycan, modulate the growth of struvite crystals in urine (Matsumoto and Funaba, 2008). To investigate the effect of the MWt of organic matter on struvite crystallization, the organic matter was fractionated using a series of membranes. COD in the unfiltered solution ( $\mathrm{S}_{\mathrm{RAW}}$ ) decreased from $4890 \mathrm{mg} / \mathrm{L}$ to $3360 \mathrm{mg} / \mathrm{L}\left(\mathrm{S}_{\mathrm{MF}}\right)$, $2310\left(S_{10 \mathrm{~K}}\right)$, and $1560\left(\mathrm{~S}_{1 \mathrm{~K}}\right)$, after passing through the $0.45 \mu \mathrm{m}$, $10 \mathrm{kDa}$, and $1 \mathrm{kDa}$ membranes, respectively. The concentrations of $\mathrm{NH}_{4}^{+}-\mathrm{N}, \mathrm{PO}_{4}^{3-}-\mathrm{P}, \mathrm{Mg}^{2+}$, and $\mathrm{Ca}^{2+}$ decreased slightly after filtration, and the ratios of $\mathrm{N}: \mathrm{P}, \mathrm{Mg}: \mathrm{P}$, and $\mathrm{Ca}: \mathrm{P}$ were within the ranges of 2.9-3.0, 0.61-0.73, and 0.92-1.14, respectively (Fig. 4).

The removal rates of $\mathrm{NH}_{4}^{+}-\mathrm{N}$ from the four solutions $\left(\mathrm{S}_{\mathrm{RAW}}\right.$, $S_{\mathrm{MF}}, \mathrm{S}_{10 \mathrm{~K}}$, and $\mathrm{S}_{1 \mathrm{~K}}$ ) were $76.72 \%, 77.32 \%, 83.69 \%$, and $89.99 \%$, respectively, and those of $\mathrm{PO}_{4}^{3}$-P were $94.62 \%, 98.69 \%, 99.21 \%$, and $99.60 \%$, respectively. The removal of both $\mathrm{NH}_{4}^{+}-\mathrm{N}$ and $\mathrm{PO}_{4}^{3}$-P increased when COD and MWt were decreased by filtration.

These results indicate that struvite crystallization was affected by organics, especially high-MWt organics (>10 kDa), and that some organics were coated on the crystals by co-precipitation, which affected the purity of the struvite product. The removal rate of $\mathrm{NH}_{4}^{+}-\mathrm{N}$ from the $\mathrm{C}_{\text {-Ca }}$ solution (without $\mathrm{Ca}^{2+}$ ) was higher than that from the $\mathrm{C}_{+\mathrm{Ca}}$ solution (with $\mathrm{Ca}^{2+}$ ). In contrast, the removal rate of $\mathrm{PO}_{4}^{3}-\mathrm{P}$ from the $\mathrm{C}_{-\mathrm{Ca}}$ solution $(85.45 \%)$ was lower than that from the $\mathrm{C}_{+\mathrm{Ca}}$ solution (98.16\%). This indicates that $\mathrm{PO}_{4}^{3}-\mathrm{P}$ competition occurred $\mathrm{Ca}^{2+}$ and $\mathrm{Mg}^{2+}$, and that the crystallized product was partly calcium phosphate. The removal rates of $\mathrm{Mg}^{2+}$ and $\mathrm{Ca}^{2+}$ were also affected by organics, and the impact was more significant in the presence of low-MWt organics. (In this study, low concentrations of organic matter corresponded to low-MWt organics, such as organic acids). The complexation of metallic cations and organic acids is known to occur under certain conditions (Iskrenova-Tchoukova et al., 2010). This would lead to removal rates of $\mathrm{Ca}^{2+}$ and $\mathrm{Mg}^{2+}$ in the $\mathrm{S}_{1 \mathrm{~K}}$ solution being much higher than in the $\mathrm{S}_{\mathrm{RAW}}, \mathrm{S}_{\mathrm{MF}}$, and $\mathrm{S}_{10 \mathrm{~K}}$ solutions. However, the removal rates of $\mathrm{Ca}^{2+}$ and $\mathrm{Mg}^{2+}$ in the simulated solutions $\left(\mathrm{C}_{-\mathrm{Ca}}\right.$ and $\left.\mathrm{C}_{+\mathrm{Ca}}\right)$ were much higher than those in $\mathrm{S}_{1 \mathrm{~K}}$.

\subsection{Precipitant characteristics}

For further investigation of the effects of organics on struvite crystallization, the crystalline morphology and elemental 

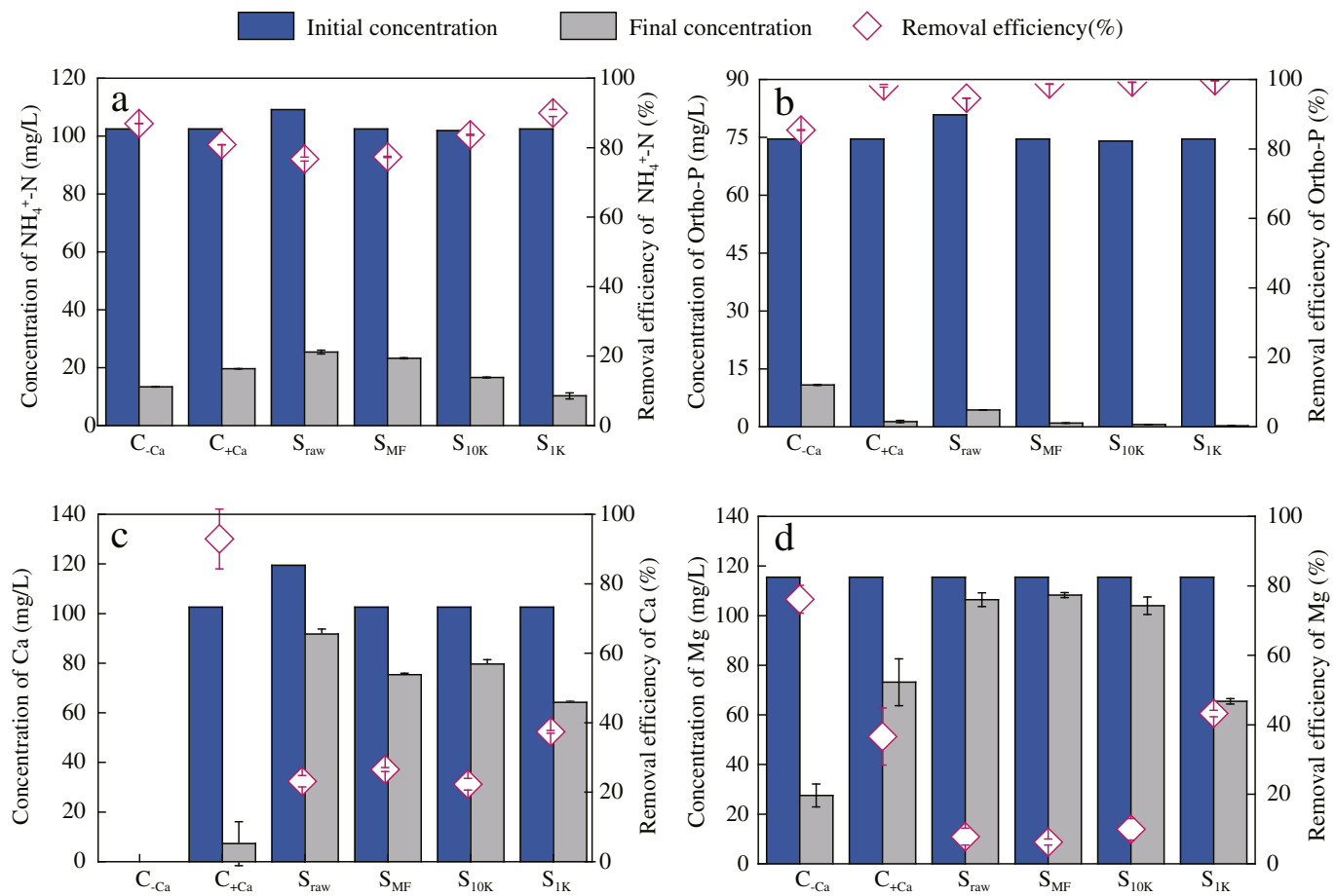

Fig. 4 - Profiles of ion variation before and after crystallization, for ammonium-nitrogen $\left(\mathrm{NH}_{4}^{+}-\mathrm{N}\right), \mathrm{PO}_{4}^{3-}-\mathrm{P} \mathrm{Mg}^{2+}$, and $\mathrm{Ca}^{2+}$.

composition were determined using an SEM and energy spectrum analysis, respectively. The $\mathrm{N}: \mathrm{Mg}: \mathrm{P}$ ratio of the crystalline material was 0.84:1.7:1 in $\mathrm{C}_{-\mathrm{Ca}}$ (mole ratio), and was 0.67:1.15:1 for the $C_{+C a}$ sample. This indicates that other precipitates, such as magnesium phosphate, were generated rather than struvite. Additionally, the ratio of $\mathrm{Mg}: \mathrm{P}$ in $\mathrm{C}_{+} \mathrm{Ca}$ was lower than in $\mathrm{C}_{\text {-Ca }}$, due to the $\mathrm{PO}_{4}^{3}-\mathrm{P}$ competition between $\mathrm{Ca}^{2+}$ and $\mathrm{Mg}^{2+}$. Consequently, the crystal morphology changed from polyhedral to amorphous (Fig. 5a and b), because of the presence of $\mathrm{Ca}^{2+}$ in the $\mathrm{C}_{+\mathrm{Ca}}$ sample.
Calcium phosphate was present in the product due to the high concentration of $\mathrm{Ca}^{2+}$ in solution. Although the SCOD of the $S_{10 \mathrm{~K}}$ solution was $2190 \mathrm{mg} / \mathrm{L}$ (much higher than for the $\mathrm{S}_{1 \mathrm{~K}}$ solution: $1545 \mathrm{mg} / \mathrm{L})$, their components of their precipitates were quite similar (Fig. 5e and f). The crystal morphology in solution was determined to be amorphous by direct observation, with the exception of the $\mathrm{S}_{\mathrm{RAW}}$ (unfiltered) solution, indicating a significant effect of the seeding material on crystal morphology. In the presence of a seed material, nucleation can occur on the seed surface, which might influence crystal

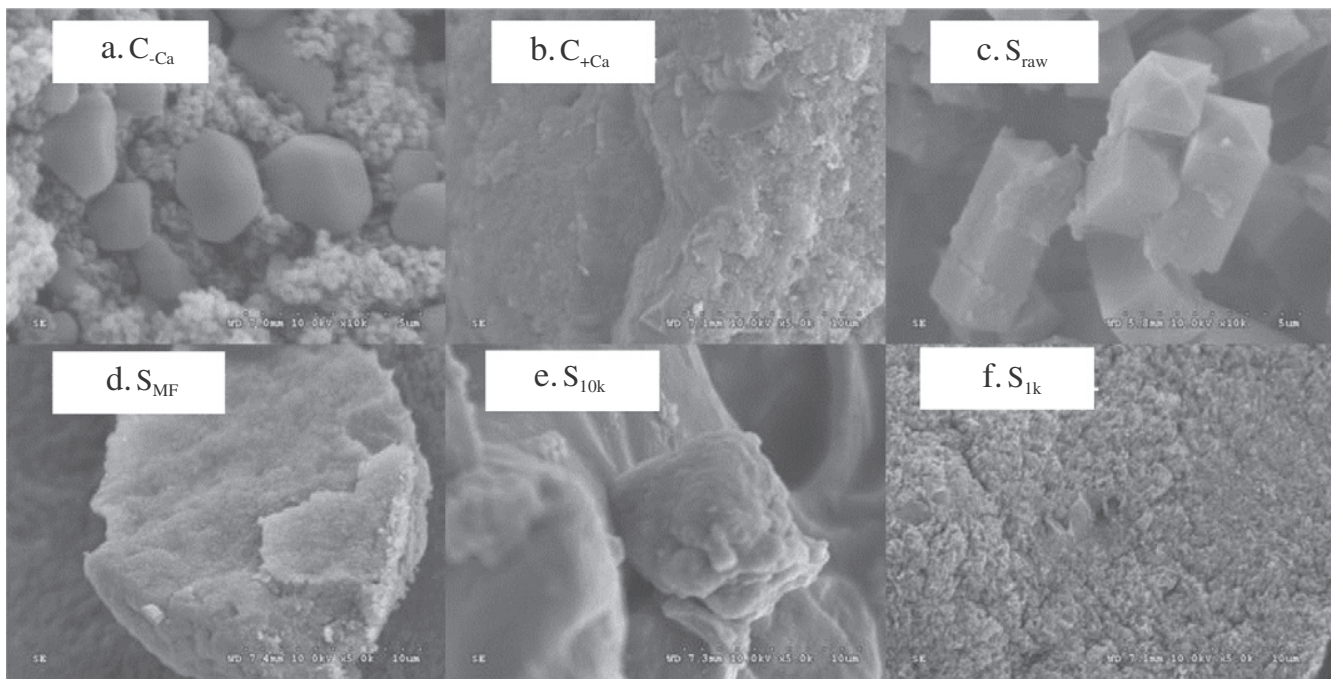

Fig. 5 - SEM images of crystal morphology at $5000 \times$ magnification. Products from: (a) Simulated solution without $\mathrm{Ca}^{2+}\left(\mathrm{C}_{-} \mathrm{Ca}\right)$; (b) Simulated solution with $\mathrm{Ca}^{2+}\left(\mathrm{C}_{+\mathrm{Ca}}\right)$; (c) Unfiltered supernatant ( $\left.\mathrm{S}_{\text {raw }}\right)$; (d) Filtrate after $0.45 \mu \mathrm{m}$ microfiltration ( $\left.\mathrm{S}_{\mathrm{MF}}\right)$;

(e) Filtration by membranes with $\mathrm{MwC}$ of $10 \mathrm{kDa}\left(\mathrm{S}_{10 \mathrm{k}}\right)$; (f) Filtration by membranes with MwC of $1 \mathrm{kDa}\left(\mathrm{S}_{1 \mathrm{k}}\right)$. 
size and morphology (Ronteltap et al., 2010). Particles of sizes $>0.45 \mu \mathrm{m}$ in the $\mathrm{S}_{\text {RAW }}$ solution might have served as seed material. However, although crystals of regular morphology formed from the $\mathrm{S}_{\mathrm{RAW}}$ solution, the ratio of $\mathrm{N}: \mathrm{Mg}: \mathrm{P}$ in the crystals was 18.74:3.84:1. This indicated that the crystals from the $\mathrm{S}_{\text {RAW }}$ solution contained a large amount of organic matter, from the perspective of component analysis through SEM-EDS elemental analysis (Fig. S5). The N: P ratios of $S_{10 k}$ and $S_{1 k}$ were 0.95 and 1.06, indicating that the phosphate was mainly struvite. The Ca:Mg ratios, which indicate the amounts of calcium salts, were $1.64\left(\mathrm{~S}_{\mathrm{MF}}\right), 0.92\left(\mathrm{~S}_{10 \mathrm{k}}\right)$, and $1.21\left(\mathrm{~S}_{1 \mathrm{k}}\right)$. The C: P ratios, representing the ratio of carbonate and phosphate, were $3.63\left(\mathrm{~S}_{\mathrm{MF}}\right), 1.63\left(\mathrm{~S}_{10 \mathrm{k}}\right)$, and $1.35\left(\mathrm{~S}_{1 \mathrm{k}}\right)$; since the initial concentrations of $\mathrm{Ca}$ and $\mathrm{Mg}$ were same, this implies that the absence of large MWt substance facilitates the precipitation of calcium carbonate. These results were determined by energy spectrum analysis of the crystal products. In the literature, needle-like, coffin-like, and trapezoidal shapes have been described as typical for struvite crystals. Morphologies that were X-shaped or dendritic were also reported as atypical (Ronteltap et al., 2010). Particle sizes $>0.45 \mu \mathrm{m}$ in the $S_{\mathrm{RAW}}$ solution have the potential to function as seed material.

Struvite crystal formation was inhibited due to the high concentration of high-MWt (>10 kDa) organic matter. It has been reported that organic ligands and macromolecular organic matter have inhibitory effects on the phosphate crystallization process (Van der Houwen and Valsami-Jones, 2001). Soluble organics from wastewaters may have formed complexes with ionic struvite reactants, thus making them less available for SAP. $\mathrm{Mg}^{2+}$ ions have been reported to react with soluble organic matter (Karabegovic et al., 2013). The large molecule binding effect on $\mathrm{Mg}$ was also observed (Fig. 4d). In addition, the co-precipitation of soluble organic compounds in struvite recovery reduces the purity of struvite (Liu et al., 2013). By contrast, the overall performance of organic matters with low molecule weight facilitated struvite crystallization, compared with the test without inoculation by organic matter $\left(\mathrm{C}_{+\mathrm{C}}\right)$. The mechanism by which organic matter affects struvite crystallization remains unclear. For low molecular weight organic matters (citric acid, succinic acid and acetic acid) (Song et al., 2014), the smaller molecular size results in weaker adsorption and less pronounced effects on the active sites of crystal nuclei. Moreover, it displays less inhibitory effect on the MAP crystallization process. A possible explanation is that organic matter could bind to ions, thereby affecting ionic activity (Ronteltap et al., 2010; Udert et al., 2003). It was found that increasing the calcium concentration reduces crystal size and inhibits struvite growth, or affects struvite crystallization and leads to the formation of an amorphous substance rather than crystalline struvite (Le Corre et al., 2005). Lower MWt matters undergo complexation with calcium, and inhibit the competitive effect with $\mathrm{Mg}^{2+}$ toward $\mathrm{PO}_{4}^{3-}$. This phenomenon was related to the functional group content and molecular size of the organic acids. Matsumoto and Funaba (2008) found that organic matter with MWt $<8 \mathrm{kDa}$ acted as a trigger for crystallization of struvite in cat urine.

These results suggest that phosphorous recovery should be placed downstream of anaerobic fermentation and coupled with sludge pretreatment. This arrangement should not only improve the release of ammonia and phosphate, but should also reduce the interfering effects organic matter of high MWt. The levels of solids, inorganics and organics in the pretreated sludge influenced SAP, which suggests that case-by-case testing and process optimization are required to improve the applicability of phosphorus recovery. These findings emphasize the need for further research into appropriate types of organic matter and the cut-off effect.

\section{Conclusions}

(1) Selective release of carbon, nitrogen, phosphorus, $\mathrm{Ca}^{2+}$, and $\mathrm{Mg}^{2+}$ can be achieved by sludge pretreatment using MW-hybrid processes. MW- $\mathrm{H}_{2} \mathrm{O}_{2}$ is the recommended sludge pretreatment process for phosphorus recovery in the form of struvite. The ratio of $\mathrm{Mg}^{2+}: \mathrm{NH}_{4}^{+}-\mathrm{N}: \mathrm{PO}_{4}^{3-}-\mathrm{P}$ was 1.2:2.9:1 in the supernatant.

(2) Pre-treatment conditions strongly affect the MWtD of the soluble matter released, mainly polysaccharides and protein, as a consequence of hydrolysis and the oxidative effect of pretreatment.

(3) Low COD facilitates the removal of $\mathrm{NH}_{4}^{+}-\mathrm{N}$ and $\mathrm{PO}_{4}^{3}-\mathrm{P}$ via crystallization, and the amorphous struvite crystals $(<1 \mathrm{kDa})$ obtained from the filtered solutions have high purity. Therefore, the present study reveals the necessity of taking into consideration the interfering effect of high MWt organic matter during struvite crystallization from sewage sludge.

\section{Acknowledgments}

This work was financially supported by the Major Science and Technology Program for Water Pollution Control and Treatment of China (No. 2015ZX07203-005, 2012ZX07202-005), and the National Natural Science Foundation of China (No. 51008297).

\section{Appendix A. Supplementary data}

Supplementary data to this article can be found online at http://dx.doi.org/10.1016/j.jes.2015.10.008.

\section{R E F E R E N C E S}

Barker, D.J., Mannucchi, G.A., Salvi, S.M.L., Stuckey, D.C., 1999. Characterisation of soluble residual chemical oxygen demand (COD) in anaerobic wastewater treatment effluents. Water Res. 33, 2499-2510.

Barlindhaug, J., Odegaard, H., 1996. Thermal hydrolysis for the production of carbon source for denitrification. Water Sci. Technol. 34, 371-378.

Bi, W., Li, Y.Y., Hu, Y.Y., 2014. Recovery of phosphorus and nitrogen from alkaline hydrolysis supernatant of excess sludge by magnesium ammonium phosphate. Bioresour. Technol. 166, 1-8.

Cheng, Z.M., Wei, Y.S., Liu, J.X., 2009. Effect of acid and alkali on phosphorus release from sludge in the microwave treatment process. Environ. Sci. 4, 1110-1114 (in Chinese). 
China, E.P.A., 2002. Standard Methods for Examination of Water and Wastewater. Chinese Environmental Science Press, China.

Doyle, J.D., Parsons, S.A., 2002. Struvite formation, control and recovery. Water Res. 36, 3925-3940.

Erdincler, A., Vesilind, P.A., 2000. Effect of sludge cell disruption on compactibility of biological sludges. Water Sci. Technol. 42, 119-126.

Eskicioglu, C., Kennedy, K.J., Droste, R.L., 2006. Characterization of soluble organic matter of waste activated sludge before and after thermal pretreatment. Water Res. 40, 3725-3736.

Gilbert, N., 2009. Environment: the disappearing nutrient. Nature 461, 716-718.

Guadie, A., Xia, S.Q., Jiang, W., Zhou, L.J., Zhang, Z.Q., Hermanowicz, S.W., et al., 2014. Enhanced struvite recovery from wastewater using a novel cone-inserted fluidized bed reactor. J. Environ. Sci. 26, 765-774.

Iskrenova-Tchoukova, E., Kalinichev, A.G., Kirkpatrick, R.J., 2010. Metal cation complexation with natural organic matter in aqueous solutions: molecular dynamics simulations and potentials of mean force. Langmuir 26, 15909-15919.

Jaffer, Y., Clark, T.A., Pearce, P., Parsons, S.A., 2002. Potential phosphorus recovery by struvite formation. Water Res. 36, 1834-1842.

Karabegovic, L., Uldal, M., Werker, A., Morgan-Sagastume, F., 2013. Phosphorus recovery potential from a waste stream with high organic and nutrient contents via struvite precipitation. Environ. Technol. 34, 871-883.

Kuo, W.C., Parkin, G.F., 1996. Characterization of soluble microbial products from anaerobic treatment by molecular weight distribution and nickel-chelating properties. Water Res. 30, 915-922.

Le Corre, K.S., Valsami-Jones, E., Hobbs, P., Parsons, S.A., 2005. Impact of calcium on struvite crystal size, shape and purity. J. Cryst. Growth 283, 514-522.

Liu, J.D., Xu, Z.X., Wang, W.G., Jin, W., 2013. The effect of organic compounds on the recovery of ammonium by struvite precipitation from swine anaerobic digester effluent. Prog. Environ. Sci. Eng. 2350-2355 (Pts 1-4 610-613).

Matsumoto, K., Funaba, M., 2008. Factors affecting struvite $\left(\mathrm{MgNH}_{4} \mathrm{PO}_{4}\right.$ center dot $\left.6 \mathrm{H}(2) \mathrm{O}\right)$ crystallization in feline urine. Biochimica Et Biophys. Acta-Gen. Subj. 1780, 233-239.

Mehdizadeh, S.N., Eskicioglu, C., Bobowski, J., Johnson, T., 2013. Conductive heating and microwave hydrolysis under identical heating profiles for advanced anaerobic digestion of municipal sludge. Water Res. 47, 5040-5051.

Parkhurst, D.L., Appelo, C.A.J., 2013. PHREEQC (Version 3) - A Computer Program for Speciation, Batch-Reaction,
One-Dimensional Transport, and Inverse Geochemical Calculations.

Ronteltap, M., Maurer, M., Hausherr, R., Gujer, W., 2010. Struvite precipitation from urine - influencing factors on particle size. Water Res. 44, 2038-2046.

Shu, L., Schneider, P., Jegatheesan, V., Johnson, J., 2006. An economic evaluation of phosphorus recovery as struvite from digester supernatant. Bioresour. Technol. 97, 2211-2216.

Song, Y.H., Dai, Y.R., Hu, Q., Yu, X.H., Qian, F., 2014. Effects of three kinds of organic acids on phosphorus recovery by magnesium ammonium phosphate (MAP) crystallization from synthetic swine wastewater. Chemosphere 101, 41-48.

Stratful, I., Scrimshaw, M.D., Lester, J.N., 2001. Conditions influencing the precipitation of magnesium ammonium phosphate. Water Res. 35, 4191-4199.

Thibault, G., 2006. Effects of Microwave Irradiation on the Characteristics and Mesophilic Anaerobic Digestion of Sequencing Batch Reactor Sludge. MASc UNIVERSITY OF OTTAWA, CANADA.

Udert, K.M., Larsen, T.A., Gujer, W., 2003. Estimating the precipitation potential in urine-collecting systems. Water Res. 37, 2667-2677.

Van der Houwen, J.A.M., Valsami-Jones, E., 2001. The application of calcium phosphate precipitation chemistry to phosphorus recovery: the influence of organic ligands. Environ. Technol. 22, 1325-1335

Wang, Y.W., Wei, Y.S., Liu, J.X., 2009. Effect of H2O2 dosing strategy on sludge pretreatment by microwave- $\mathrm{H}_{2} \mathrm{O}_{2}$ advanced oxidation process. J. Hazard. Mater. 169, 680-684.

Wang, Y., Gui, C., NI, X., CHEN, M., WEI, Y., 2015. Multivariate analysis of sludge disintegration by microwave-hydrogen peroxide pretreatment process. J. Hazard. Mater. 283, 856-864.

Wong, W.T., Chan, W.I., Liao, P.H., Lo, K.V., 2006a. A hydrogen peroxide/microwave advanced oxidation process for sewage sludge treatment. J. Environ. Sci. Heal. A 41, 2623-2633.

Wong, W.T., Chan, W.I., Liao, P.H., Lo, K.V., Mavinic, D.S., 2006b. Exploring the role of hydrogen peroxide in the microwave advanced oxidation process: solubilization of ammonia and phosphates. J. Environ. Eng. Sci. 5, 459-465.

Xiao, Q.C., Yan, H., Wei, Y.S., Wang, Y.W., Zeng, F.G., Zheng, X., 2012. Optimization of $\mathrm{H}_{2} \mathrm{O}_{2}$ dosage in microwave- $\mathrm{H}_{2} \mathrm{O}_{2}$ process for sludge pretreatment with uniform design method. J. Environ. Sci. 24, 2060-2067.

Ye, Z.L., Shen, Y., Ye, X., Zhang, Z.J., Chen, S.H., Shi, J.W., 2014. Phosphorus recovery from wastewater by struvite crystallization: property of aggregates. J. Environ. Sci. 26, 991-1000. 